\title{
Lições \\ além do teatro
}

ANTONIO DIMAS

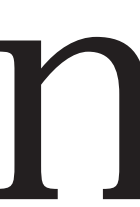

a desvalorizada profissão do magistério, há momentos de privilégio, alguns extensos. São aqueles em que a convivência profissional recompensa o desânimo eventual, fomentado pelos que, de plantão no poder, desacreditam a educação, sobretudo porque já se safaram das limitações materiais que qualquer remuneração irrisória acarreta.

O convívio profissional com Decio de Almeida Prado, por mais de dez anos, foi um desses momentos privilegiados que nenhum currículo da atual universidade brasileira, ansiosa por pontos, números, gráficos e teorias, consegue acolher e nem de longe imaginar. Vê-lo entrar nas salas já era uma aula de finura pessoal, de sobriedade e de camaradagem, sem demagogia. Sua voz modulada, seu sorriso maroto, seus olhos inquietos, sua informação medida e seu humor constante eram um modelo de desempenho docente, cujo interior mais sólido abrigava um extenso conhecimento de cultura brasileira, sempre conectada à de boa procedência européia ou norte-americana. Tranqüilo diante das teorias que vira-e-mexe assaltam e sobressaltam o meio, Decio caminhava seguro pela valorização do teatro brasileiro, sem, no entanto, cair na esparrela do nacionalismo apressado e juvenil, nem dodeslumbramento perante o forâneo. Haja

ANTONIO DIMAS

é professor do

Departamento de Letras Clássicas e Vernáculas da FFLCH-USP. vista sua bibliografia indispensável, capaz de ensinar - mais que teatro brasileiro - um comportamento crítico equilibrado, sem condescendência, e receptivo, sem escancaramento. Nunca the foram indiferentes a ciência, a consciência, a independência, a tolerância, a perseverança e a urbanidade, pressupostos da crítica justa, segundo Machado. Acompanhá-lo na montagem e formalização de suas pesquisas foi um regalo metodológico (váláo palavrão!), que substituiu muitas aulas desnecessárias e enfadonhas, dadas com sisudez profissional por quem confunde seriedade com aridez. Num de seus prefácios, Decio de Almeida Prado, ao agradecer a um dos colegas por ter-lhe corrigido as provas de novo livro, definiu de modo certeiro o convívio saudável, sem acotovelamento: "Esses serviços que prestamos uns aos outros, essas colaborações espontâneas, carregadas de afetividade, são das coisas mais agradáveis da vida universitária, na qual trabalhamos sempre tendo em vista um objetivo maior do que a contribuição particular de cada um".

Guiado por esse sentimento de coesão profissional cimentado pelo afeto, Decio foi responsável por um clima de cordialidade, cavalheirismo e serenidade, mesmo quando as tensões e os interesses pessoais ameaçavam aflorar. Na iminência desse risco, sua palavra elegante, quase sempre humorada, desfazia o desconforto e desarmava os ímpetos, sem desqualificá-los, nem desmerecê-los. Mais que professor de teatro e de Brasil, Decio foi, como outros dessa geração preciosa, um professor de elegância pessoal, acadêmica e intelectual. E isso, não há livro que ensine. 